\title{
Aiming for Intrasectorality: Public Safety and Health
}

\author{
Luiz Fernando de Lima Paulo', Marco Akerman¹,
}

\section{Abstract}

Violence and accidents are the second cause of death. Its consequences show an increase in expenses with emergency assistance and rehabilitation, as demonstrated by the Inter-American Bank. In view of the seriousness of the issue, in 1994 the Pan American Health Organization held a conference presenting health experts and ministers with an endemic picture of violence in the country.

Intrasectorality plays an important role in the search for efficient solutions capable of delivering better results for society and public health. Between September and December 2014, the Civil and Military Police of the western region of São Paulo performed an intrasectorial work based on new management practices. Crimes of interest to public health were accompanied by the criminal intelligence system. It is noted that there was a significant reduction in crimes of interest in the West Region of São Paulo.

The results shows that the complete cycle of police and/or unification of Police Institutions are alternatives for better public management and, consequently, reduction of crime.

\section{Introduction}

Violence is a socio-historical phenomenon and accompanies the whole experience of humanity. Therefore, it is not itself a public health issue. It becomes a problem for the area because it affects individual and collective health and requires, for prevention and coping, formulation of specific policies and organization of practices and services peculiar to the sector [1].

The World Health Organization (WHO) in 1993 World Health Day celebration repeated in its justification a statement attributed to William Forge, that: since time immemorial, infectious diseases and violence are the main causes of premature deaths [2].
1 ABC Medicine College. Public Health Department, Santo André, SP, Brazil.

2 São Paulo University (Universidade de São Paulo - USP), São Paulo, SP, Brazil.

\section{Contact information:}

\section{Luiz Fernando de Lima Paulo.}

Address: Public Health Department. 821 Príncipe de Gales Avenue, Príncipe de Gales, CEP: 09060-650, Santo André, SP, Brazil.

巨"proflimapaulo@gmail.com 
Today, in its worldwide report on violence and health, WHO reports that over one million people die each year and many other suffer nonfatal injuries from violent causes [3].

In Brazil, since the beginning of the $80 \mathrm{~s}$, accidents and violence are the second cause of death and, for the wide range of 5 to 39 years, are the main problem of victimization that leads to death [4].

The consequences of violence that reach the health system, among other aspects, show an increase in expenses with emergency, care and rehabilitation, much more costly than most conventional medical procedures [4].

The Inter-American Development Bank calculations, cited by Briceño-Leon [5], estimate that 3.3\% of Brazilian GDP is spent on direct costs of violence, a figure that rises to $10.5 \%$ when including indirect costs and transfers of resources. This author, speaking of Latin America as a whole, states that the damages and transfers of resources that are caused by the violence amount to $14.2 \%$ of the region's GDP and are equivalent to 168 million dollars. In order to have an idea of the significance of the estimate of the direct costs of violence in the country (3.3\% of GDP), it is three times higher than the amount currently invested in Brazil in Science and Technology [5].

Despite all of the above reasons, the inclusion of violence in the health sector has been occurring very slowly. The first way of introducing the subject, to which William Forge [2] refers, mentioned above, has been taking place within the biomedical logic itself in the punctual and specific care of injuries, traumas and deaths. These categories are traditionally referred in the International Classification of Diseases (ICD) as "external causes".

The concept of mortality from external causes has always included homicides, suicides, and accidents; and of morbidity, injuries, poisonings, wounds, fractures, burns and intoxications by interpersonal and collective aggressions [1].
In the health area, studies and actions are still very modest, even in the literature of countries where there is traditionally a strong research tradition [6].

Officially, only since the 90s the Pan American Health Organization (PAHO) and WHO started talking specifically about "violence" (not just "external causes"), bringing together the various discussions (always dispersed and with little institutional legitimacy until then) that had been taking place in different spheres and in some countries [1].

In 1994, PAHO called the Ministers of Health of the Americas, researchers and experts for a conference on the topic [7].

Conference participants understood that the epidemiological transition of the countries of the region presented an old issue with new colors and evidence, and it was necessary to define it in its historical specificity and map it so that it would be treated with the distinctions of the sector and in the aspects of intrasectorality: Violence, by the number of victims and by the magnitude of the organic and emotional sequels it produces, has acquired an endemic character and has become a public health problem in many countries [...] [7].

In 2002, WHO produced a Global Report [3] in which the term "external causes", traditionally used to categorize the subject in the International Classification of Diseases and Diseases (ICD), was replaced by "Violence and Health".

In 2005, the Ministry of Health, together with the Brazilian representation of Opas and Claves/ Fiocruz, produced and disseminated a report, following more or less the line of the international text, entitled Impact of violence on the health of Brazilians [8].

It is noted the efforts of the institutes and world health organizations to control violence and, consequently, the improvement of the health conditions of society, however, Public Safety Institutions play an important role in controlling violence in the country. 
Thus, intrasectorality, despite being a recent construction, plays an important role in guaranteeing universal human rights [9], since intrasectoral work supposes not only the dialogue or the simultaneous work between the actors involved, but the search for results integrated with an emphasis on a new management strategy for public administration [10].

Intrasectoral management appears as a new possibility to solve these problems that affect a population that occupies a certain territory. This is an important perspective because it points to an integrated view of social problems and their solutions. The aim is to optimize scarce resources by seeking integrated solutions, since the complexity of social reality requires a comprehension that is not exhausted within a single social policy [11].

Thus, the objective of the present study is to demonstrate the importance of the structuring intrasectoriality of public policies that allow an improvement in the public safety and health conditions.

\section{Method}

\section{Design}

This is a descriptive study with data analysis from September 2014 to December 2015.

\section{Participants and centers}

Participated in the research, the São Paulo State Military Police (West 5 Area Police Command) and the São Paulo State Civil Police, (3rd West Sectional Police Station), both, Police Institutions of Brazil, with different functions between them. Through the Operational Planning Section of the West Region of São Paulo (Metropolitan Police Command), the criminal indicators of interest to public health and the reflections of the intrasectorality between the two Police Institutions were analyzed.

\section{Intervention}

The Federative Republic of Brazil Constitution, promulgated in 1988, provides, in article 144, the existing police in Brazil, as well as their respective functions. It is up to the Military Police of the São Paulo State, the preventive and ostensible uniformed policing. In turn, Civil Police is responsible for registration and investigation, through judicial police actions.

Thus, there are 2 Police Institutions that perform part of the Police actions. The first, the Military Police of the State of São Paulo, acts in preventive patrolling and immediate repression, that is, preventing crimes from occurring or soon after committing crimes, and must drive persons or objects to the Civil Police, which will conduct the registration and the investigation with a different team from the first.

Due to the division of the police actions (absence of the complete police cycle), the registration of the criminal acts encumbers part of the Military Police force in the presentation of the report in the Civil Police station, which significantly increases the probability of new criminal events, including those of public health concern, and consequently, greater harm to society and public health.

Through a case of intrasectorality between the two Police Institutions, since September 2014, the Military Police of São Paulo State transmitted information and drove persons and objects to the Civil Police through a mere report bulletin without the personal presence of the Military Police Agents, in an attempt to reduce the length of stay of the police force and vehicles in the Civil Police districts, increasing the length of stay in the regions more affected by crime, in an attempt to reduce criminal indicators and the consequences for society and public health.

\section{Outcome measures}

In September 2014, the Intrasectorality between the Civil and Military Police was started, using a new management model and records of police reports, in order to increase the length of stay of the military police force in the regions with the highest inciden- 
ce crime, aiming to reduce crime and the impact of violence on public health.

It was verified, through the criminal information system (Infocrim), the variation of criminal indicators of interest for public health, in order to analyze the validity of intrasectorality between the two Police Institutions, the direct effects on public health and on the aiming to contribute to the restructuration of public security in the State of São Paulo and Brazil, making possible the improvement of the control of violence in the country.

The first analysis covered 3 police districts $-14^{\text {th }}$ Police District, $15^{\text {th }}$ Police District and $51^{\text {st }}$ Police District, between October and December 2014. In a second moment, it was analyzed from January to December 2015, with expansion of intrasectorality for the entire western region of the city of São Paulo, with the same variables and results that indicated the need for readjustment of public security in Brazil.

\section{Data analysis}

Qualitative variables were presented on the basis of the International Code of Diseases (ICD) and crimes that directly affect public health in expenditures for the single health system (SUS), such as willful homicide, willful bodily injury, rape, firearms crimes and robbery. The quantitative variables were extracted from the Criminal Information System (Infocrim) of the São Paulo State Public Security Bureau

To analyze the quantitative variables, we used descriptive statistics with a significance level of $95 \%$. The software used was Bioestat 5.0 for Windows.

\section{Results}

In the period between October and December 2014, compared to the same period of the previous year, they show a reduction in most of the crimes analyzed: Table 1: Number of crimes during the intrasectoral period between Military Police and Civil Police. (Figure 1)
Table 1. Time to record criminal reports in Police Stations in the West Region of São Paulo (São Paulo State Civil Police) before and after the management strategy adopted between the two Police Institutions.

\begin{tabular}{|c|c|c|c|c|}
\hline \multirow[b]{2}{*}{ Crimes } & \multicolumn{2}{|c|}{ Year } & \multirow[b]{2}{*}{ Difference } & \multirow{2}{*}{$\begin{array}{c}\text { Percentual } \\
\%\end{array}$} \\
\hline & $\begin{array}{c}\text { Oct } \\
2013\end{array}$ & $\begin{array}{c}\text { Dec } \\
2014\end{array}$ & & \\
\hline $\begin{array}{l}\text { Willful Bodly } \\
\text { Injury }\end{array}$ & 162 & 160 & -2 & -1 \\
\hline $\begin{array}{l}\text { Willful } \\
\text { Homicide }\end{array}$ & 2 & 0 & -2 & -200 \\
\hline Rape & 2 & 4 & 2 & 100 \\
\hline $\begin{array}{l}\text { Firearms } \\
\text { Crimes }\end{array}$ & 2 & 0 & -2 & -200 \\
\hline Robbery & 1 & 2 & 1 & 100 \\
\hline Total & 169 & 166 & -3 & -2 \\
\hline \multirow[b]{2}{*}{ Crimes } & \multicolumn{2}{|c|}{ Year } & \multirow[b]{2}{*}{ Difference } & Percentual \\
\hline & $\begin{array}{c}\text { Jan/Dec } \\
2014\end{array}$ & $\begin{array}{c}\text { Jan/Dec } \\
2015\end{array}$ & & $\%$ \\
\hline $\begin{array}{l}\text { Willful Bodly } \\
\text { Injury }\end{array}$ & 3931 & 3781 & -150 & -4 \\
\hline $\begin{array}{l}\text { Willful } \\
\text { Homicide }\end{array}$ & 143 & 133 & -10 & -7 \\
\hline Rape & 118 & 148 & 30 & 25 \\
\hline $\begin{array}{l}\text { Firearms } \\
\text { Crimes }\end{array}$ & 27 & 15 & -12 & -44 \\
\hline Robbery & 18 & 13 & -5 & -28 \\
\hline Total & 4259 & 4111 & 148 & -3 \\
\hline
\end{tabular}

Figure 1: Number of Willful Bodly Injury between January and December of 2014 compared with equal period in 2015.

\begin{tabular}{cc}
\hline \multicolumn{1}{c}{143} \\
\hline \\
\hline \\
\hline $\operatorname{Jan} / \operatorname{Dec} 2014$ \\
\hline $\operatorname{Jan} / \operatorname{Dec} 2015$ \\
\hline
\end{tabular}




\section{Discussion}

Changes in the public management strategy become prerequisites for development, since proposing resolution to face the expressions of the social affairs is a challenge to social policies.

We consider intrasectorality as a public policy management model that is essentially based on contractual relationships between different sectors where responsibilities, goals and resources are shared, making possible a relationship of respect for the autonomy of each sector, but also interdependence [11].

It is noted that the articulation of knowledge and experiences has achieved synergistic results in the face of extremely complex situations [10].

...the intrasectoral management emerges as a new possibility to solve these problems that affect a population that occupies a certain territory. This is an important perspective because it points to an integrated view of social problems and their solutions. The aim is to optimize scarce resources by seeking integrated solutions, since the complexity of social reality demands a look that is not exhausted within a single social policy

Junqueira, 1999.

It is verified that the developed intrasectorality was able to provide integrated results through dialogue, management and simultaneous work among those involved, presenting the efficiency of new strategies of public administration [10].

The reflections of intersectoral and/or intrasectorial measures achieve, directly, public health, since the reduction in the number of crimes of interest (external causes) burdens with less impact the budget for the users of the Unified Health System (SUS), main recipient of victims of violence [12].

The data also show that the efficiency of the measure developed in the western region of São Paulo, pushed the intra-regional boundaries, since, after the analysis of similar measures developed in different regions of the state, the resolution No. 57, 08 May 2015, from São Paulo State Secretariat of Public Security was issued, regulating intrasectorality between the two Law Enforcement institutions throughout the state of São Paulo, which theoretically entail the reduction of crime in the state, including those of public health concern.

\section{Conclusions}

Intrasectorality is an important tool for the modernization of public administration, capable of improving the direct results in the area of action, as well as indirectly in other areas, as it happens with the public health for the reduction of morbidity and mortality by external causes, however, the division of the work between the two institutions makes the results little expressive, statistically observing.

The dichotomized police model adopted by Brazil appears to be totally bureaucratic, formal and counterproductive, serving as a motivation for rivalries between the Police Institutions. The entire police cycle is practiced in several Police Institutions in the world, such as Portugal, France, Spain, Belgium, Italy and Germany, thereby reducing bureaucracy, increasing its efficiency and therefore theoretically capable of bringing better results for public health and Brazilian society.

In this way, the intrasectorality is valid and effective, however, the revision of the constitutional text, giving both State Institutions the complete police cycle, will theoretically bring greater public health and safety, until the adjustment of systems and processes for unifying the security police forces.

\section{Ethics approval}

The Ethics Committee(s) of Faculty of Medicine of ABC approved this study, under number CAAE: 25030814.5.0000.0082, 516.368. All participants gave written informed consent before data collection began. 


\section{Competing interests/Source(s) of support/ Acknowledgements}

None.

\section{References}

1. Minayo MCS.The inclusion of violence in the health agenda: historical trajectory. Revista Ciência \& Saúde Coletiva, v.11 (sup), 2007, p. 1259-1267.

2. Organização Mundial de Saúde. Salud Mundial. Genebra: OMS; 2003.

3. Organização Mundial de Saúde. Relatório mundial sobre violência e saúde. Brasília: OMS/Opas; 2002.

4. Minayo MCS. Violência, um problema para a saúde dos brasileiros: introdução. In: Souza ER, Minayo MCS, organizadores. Impacto da violência na saúde dos brasileiros. Brasília: Editora do Ministério da Saúde; 2005. p. 9-33.

5. Briceño-León R, organizador. Violencia, sociedad y justicia en América Latina. Buenos Aires: Clacso; 2002.

6. Wolf RS. Maltrato em ancianos. In: Anzola Perez E. Atención de los ancianos: um desfio para los noventa.Washington D.C. : Opas; 1995. p. 35-42.

7. Organização Pan-americana de Saúde. Violência y Salud. Resolución n XIX.Washington D.C. : Opas; 1994.

8. Brasil. Ministério da Saúde. Secretaria de Vigilância em Saúde. Impacto da violência na saúde dos brasileiros.Brasília: Ministério da Saúde; 2005.

9. Maia M. Gestão Social: reconhecendo e construindo referências. In: Revista Virtual Textos \& Contextos, n 4, dez, 2005.

10. Inojosa R. Sinergia em políticas e serviços públicos: desenvolvimento social com intersetorialidade. In: Cadernos Fundap, n. 22, p.102-110, 2011

11. Junqueira LAP. Descentralização, intersetorialidade e rede como estratégias de gestão da cidade. In: Revista FEA-PUC-SP, São Paulo, v. 1, p. 27, 57-72, nov. 1999.

12. Melione LPR; Mello-Jorge MHP. Gastos do sistema único de saúde com internações por causas externas em São José dos Campos, São Paulo, Brasil. Cad Saúde Pública, n.24, v.8, p-18141824, ago, 2008.

Publish in International Archives of Medicine

International Archives of Medicine is an open access journal publishing articles encompassing all aspects of medical science and clinical practice. IAM is considered a megajournal with independent sections on all areas of medicine. IAM is a really international journal with authors and board members from all around the world. The journal is widely indexed and classified Q2 in category Medicine. 